\title{
Overweight Effects on Metabolic Rate, Chronic Diseases, Time Perception, Aging, and Lifespan: a Systematic Review
}

Kuat Oshakbayev ( $\square$ okp.kuat@gmail.com )

Medical center ANADETO of the Republic of Kazakhstan https://orcid.org/0000-0003-4883-295X

Gulnara Bedelbayeva

Kazahskij Nacional'nyj Medicinskij Universitet imeni S.D. Asfendiârova: Asfendiyarov Kazakh National Medical University

Meruyert Gazaliyeva

Karaganda State Medical Institute: Karaganda State Medical University

Bibazhar Dukenbayeva

Astana Medical University: Astana medical university

Attila Tordai

Semmelweis University of Medicine: Semmelweis Egyetem

Abdul Rakhimi Sabir

Oxford University: University of Oxford

\section{Research}

Keywords: Overweight, Metabolic rate, Time-flow perception, Aging, Lifespan, Gain weight power

Posted Date: August 2nd, 2021

DOl: https://doi.org/10.21203/rs.3.rs-718090/v1

License: (c) (1) This work is licensed under a Creative Commons Attribution 4.0 International License.

Read Full License 


\section{Abstract}

Background: The hypothesis that metabolic rate is inversely correlated with lifespan has long been debating. Another area of controversy is an evidence of a relationship between metabolic rate and time perception, and aging. Aim: to study the impact of overweight and food intake on metabolic rate, timeflow perception, chronic diseases, aging, lifespan; difficulties in weight loss.

Methods: Design: a systematic review. Setting and Participants: Web of Science, Scopus, Science Direct, Kopernio, PubMed, Mendeley were searched for articles published from January 1979 until March 2020. The study bases on a viewpoint supported by a systematic literature review of 3612 articles published worldwide.

Results: In total, 107 full-text articles were assessed for eligibility. From them, 25 articles were excluded with reasons. Overweight and food intake are the main causes of accelerating metabolic rate. By age, the body should less calorie intake due to decreasing metabolic rate. Body capability to gain weight is integral indicator of body energy reserve that depletes after weight gain. Increased metabolic rate creates a delayed time-flow perception and accelerates aging. Metabolic rate and lifespan are inversely correlated. Weight loss is a good tool to delay aging and increase lifespan. Very-low-calorie diets and to manage metabolic intoxication should use at weight loss.

Conclusions: The findings support overweight with overeating increases metabolic rate that in turn delays time-flow perception, increases disease, accelerates aging, limits lifespan. For weight loss has to manage a very-low-calorie diet.

\section{Introduction}

The prevalence of overweight burden is increasing among population of all countries of the world. Overweight has an adverse effect on health and lifespan. (1) The risk of chronic diseases incidence and mortality is rising in the last several decades despite better hygiene, modern detection technologies and discovery of antibiotics, subsequent 2-3 generations are sicker than previous generations at same age. $(1,2)$

The hypothesis metabolic rate (MR) is inversely correlated with lifespan has been long debating. $(3,4)$ MR increases to repair cellular damage using metabolic substrates. (5) MR inversely correlates with aging and lifespan. Physical activity, correlated with MR and estimated by mean walking speed, was positively correlated with mitochondrial DNA copy number. MR may increase to provide energy to repair a cellular damage. (6) Ambient temperature increasing in optimal range improves body fertility, but decreases body lifespan. (7) High MR across 46 species was associated with lower survival but other factors also influence to survival and metabolism. (8)

Many researchers discuss the idea that overweight may accelerate the rate of aging and shortening lifespan and health span. (9) Overweight is associated with excess mortality and greatly increased 
coronary artery disease incidence. (10) Another area of controversy is evidence of the relationships between overweight and MR, time-flow perception (TFP), aging, lifespan.

Humans have a psychological mechanism for perception of slowing time down as motion speeds up, (11) or every event and its repetition-expectations differentially affect the perception of time. (12) Considering how MR might influence time perception helps reduce the existing gap between our understanding of physics and our understanding of human physiology.

Weight loss methods improve in multiple cardiovascular risk markers, reduce in medication, improve MR. $(13,14)$ However, not every weight loss method can support metabolic health, reduce in energy expenditure, reduce oxidative damage, and delay age-associated declines in physiological function. (15)

The impact of overweight on MR, health and diseases, aging and lifespan was separately investigated before, but all in conjunction was not studied, especially the impact of overweight and MR on TFP. The present review helps to fill in this gap that aim was to study the impact of overweight and food intake on MR, TFP, chronic diseases, aging, and lifespan; difficulties in weight loss.

\section{Methods}

- Literature systematic analytic review;

- Details of the historical subject matter and clinical/research practice, including results, authors' reflections, and lessons learned as applicable.

Review questions.

What is the association of overweight with MR, TFP, chronic diseases, aging, and lifespan? What are difficulties in weight loss?

Search strategy.

We searched Web of Science, EBSCO (Medline Complete), Science Direct, Scopus, Google Scholar, Kopernio, PubMed, Mendeley, and Ovid (Wolter Kluwer) for articles published from January 1979 until November 2020. PRISMA checklist is provided as an additional file. The following search terms were used together and separately: body weight, overweight; metabolic rate; time-flow perception/ perception of flow time/ perception of time passage; aging; lifespan/ life expectancy; a power to gain weight.

The search strategy included only terms relating/ describing to the exposure/ intervention. To this topic devoted not so much literature worldwide, especially, to the association of overweight, perception of time passage, MR and gravitation (gravity), aging, lifespan. We searched the literature and recorded the search results. These records were screened and eligibility criteria applied, a smaller number of articles remained. There were no language restrictions. The searches were re-run before final analyses, and applicable 
further studies retrieved for inclusion. Two researchers independently assessed and then reached an agreement on the included studies and the extracted data. All types of studies were included.

\section{Results And Discussion}

In the initial search, 3612 relevant articles were identified. 208 records after duplicates were removed. After the titles, abstracts, and texts were evaluated, 1151 articles were excluded (Fig. 1). In total, 107 fulltext articles were assessed for eligibility. From them, 25 articles were excluded for the following reasons: twelve articles were excluded because they did not distinguish obesity from overweight; thirteen articles were excluded because they did not provide aging process and lifespan. Therefore, the final sample comprised of 82 articles.

\section{Body mass, Food intake, Metabolic rate}

Basal metabolic rate (BMR) represents $75-80 \%$ of a total daily energy expenditure, and only $20-25 \%$ of a total energy expenditure is used for external work as physical and mental activity. $(3,4,16)$ Therefore, BMR can imply MR as an indicator of the amount of energy expenditure per unit time.

BMR of people with the same weight may differ by up to $25 \%$. (17) For instance, in tropical populations, BMR is $15-20 \%$ lower compared to Europeans and Americans. (18) Overweight can change BMR on 20$50 \% .(19)$

The largest part of BMR spends on food intake and digestion. On average, a 100-kcal surplus in daily energy expenditure and positive one percent shift in 24-hour respiratory quotient were associated with independent increases in ad libitum food intake of approximately 175 and $204 \mathrm{kcal} /$ day, respectively, indicating that both the underlying metabolism and substrate oxidation are competing drives for food intake. (20) For each $100 \mathrm{kcal} /$ day extra intake, the body expends $\approx 50 \mathrm{kcal} /$ day from own reserve.

Daily extra food intake increases metabolic stress to the body. Excess food intake increases both BMR and active metabolism. (21) Over-metabolism consumes body "vital energy".

The body expends more energy on excess protein digestion, for instance, protein increases thermogenic effect up to $25 \%$ of total energy expenditure. (22) A protein diet speeds up MR. Protein metabolism loads all detoxification organs as kidneys, liver, skin, and lungs. A simple restriction of food intake decreases in MR by $45 \%$. (23)

The body on Earth needs to have muscle mass to overcome gravitation. Body fat also consumes the body energy. When the body doesn't need in muscle mass, it will hypotrophy as it takes place in open cosmos, (24) but the trend does not happen with fat mass. Fat mass does not atrophy in the body and it can live for many years.

\section{Overweight, Metabolic rate, Gravitation, Time-flow perception}


According to both classical Newton's physics and quantum physics (Relativity theory), the body speed and time are inversely correlated. (25) Slowing time creates a delayed TFP. MR increases accordingly with increase of body speed. Consequently, with increase in MR the TFP slows down.

Gravitation also delays time flow (gravitational time dilation) (26) and directly proportional influences body MR. (27) The stronger gravitation, the slower the TFP. MR is reduced by $19 \%$ at 'zero gravitation'. (28) Gravitation influences on time-flow both directly and through effects on body MR. Gravitation boosts MR and slows TFP. (11)

TFP is accelerated with human aging (29) also due to slowing MR down.

Human activity depends on metabolism, (30) therefore MR influences on TFP.

Overweight accelerates MR. (31) Overweight people more often complain of fatigue and discomfort. Delayed TFP also occurs in people with overweight when they feel tired. The fatigue feeling may be associated with a decline of endurance threshold. (32) According to the Thermodynamic Second Law every desired result takes effort.

A delayed TFP is observed in people waiting some event, or engaged in unloved affair. (12) Obviously, 'waiting process' speeds MR up.

Delayed TFP is also observed in childhood (they have a fast MR), and accelerated TFP in old people (they have a slow MR). Increased MR delays TFP.

Table 1 shows the summary result of studies assessing the impact of MR on TFP. 
Table 1

Summary of studies assessing the impact of metabolic rate on time-flow perception

\begin{tabular}{|llll|}
\hline Authors & Protocol & $\begin{array}{l}\text { Metabolic rate } \\
\text { parameters }\end{array}$ & $\begin{array}{c}\text { Time-flow } \\
\text { perception }\end{array}$ \\
\hline $\begin{array}{l}\text { Ulmer HV et al., } \\
1996(72)\end{array}$ & Human study & $\begin{array}{l}\text { MR at heavy } \\
\text { exercise }\end{array}$ & Delay \\
\hline $\begin{array}{l}\text { Misanin JR et al., } \\
\text { 1998(73) }\end{array}$ & Animal study & $\begin{array}{l}\text { MR at low } \\
\text { temperatures }\end{array}$ & $\begin{array}{l}\text { Slow the internal } \\
\text { clock }\end{array}$ \\
$\begin{array}{l}\text { Block RA et al., } \\
\text { 1999(74) }\end{array}$ & $\begin{array}{l}\text { Human studies (Review, 20 } \\
\text { experiments) }\end{array}$ & MR in children & Delay \\
$\begin{array}{l}\text { Harms JK et al., } \\
\text { 2003(35) }\end{array}$ & Human study & Increasing MR & Delay \\
\hline $\begin{array}{l}\text { Hancock P et al., } \\
\text { 2010(33) }\end{array}$ & Human study ( $=320)$ & MR in young age & Delay \\
\hline $\begin{array}{l}\text { Healy K et al., } \\
\text { 2013(30) }\end{array}$ & Human and Animal studies & $\begin{array}{l}\text { Body mass } \\
\text { increasing }\end{array}$ & Delay \\
\hline MR, metabolic rate. & & & \\
\hline
\end{tabular}

The younger human, the greater tendency to overestimate the time-flow. The older human, the greater tendency to underestimate the time-flow. (33)

After body growth stops (23-25 years), MR becomes moderate, TFP begins to accelerate. It is related to an energy-saving mode. The mode increases lifespan. (34) Barbi et al. showed that mortality is constant at extreme ages. Human death rates increase exponentially up to age 80 , then decelerate, and plateau after age 105. There's no limit to longevity, says the study that revives human lifespan debate.

While goes MR down a nutrient intake should be decreased accordingly. Nowadays, modern eating habit increases overweight prevalence.

Animal world also confirms the relationship between MR and TFP. The slower metabolism (cold-blooded animals) the more TFP accelerates. (30) In turtles (slow metabolism), time seems like "go fast", but in hummingbirds (fast metabolism), time seems like "go slowly". (35) The faster MR, the slower events change around. Every increase in MR slows TFP down.

MR in men and women is different, TFP is also different between them. (36) Possibly, lifespan in women is longer than in men as the result.

Body growth factors decrease in lifespan. (37) Attempts to accelerate metabolism lead to aging and diseases. Excess metabolism reduces body reserve. The faster body growth, the shorter lifespan. (38) The Hayflick limit evidences body energy is finite: the more cell mitosis, the shorter cell lifespan. (39) 
Nutrient intake should be optimized for energy eco-mode.

\section{Overweight, Metabolic rate, Energy expenditure, Lifespan}

Weight, MR and body reserve are correlated to each other. The more weight, the more body maintains a higher MR. Increase in bodyweight and metabolic activity are accompanied by rapid body growth, but short lifespan. (40)

Table 2 presents summary of studies influence of a high MR on aging, survival and lifespan in humans and animals. 
Table 2

Summary of studies assessing the impact of a high metabolic rate on aging, survival and lifespan.

\begin{tabular}{|c|c|c|c|c|}
\hline Authors & Protocol & Participants & $\begin{array}{l}\text { Measurements of } \\
\text { high MR }\end{array}$ & $\begin{array}{l}\text { Aging/ } \\
\text { Survival/Lifespan }\end{array}$ \\
\hline $\begin{array}{l}\text { Negasheva } \\
\text { M et al., } \\
\text { 2014(75) }\end{array}$ & $\begin{array}{l}\text { Human } \\
\text { study }\end{array}$ & $\begin{array}{l}119 \text { (aged } 60 \text { to } 104- \\
\text { years-old females) }\end{array}$ & Biological age & Aging accelerated \\
\hline $\begin{array}{l}\text { Keil G et al, } \\
2015(76)\end{array}$ & $\begin{array}{l}\text { Human } \\
\text { and } \\
\text { Animal } \\
\text { studies }\end{array}$ & & Body temperature & $\begin{array}{l}\text { Aging accelerated } \\
\text { and } \\
\text { Lower lifespan }\end{array}$ \\
\hline $\begin{array}{l}\text { Ravussin E } \\
\text { et al., } \\
2015(77)\end{array}$ & $\begin{array}{l}\text { Human } \\
\text { study }\end{array}$ & $\begin{array}{l}218 \text { (females and } \\
\text { males) }\end{array}$ & $\begin{array}{l}\text { Resting metabolic } \\
\text { rate }\end{array}$ & Aging accelerated \\
\hline $\begin{array}{l}\text { Geisler C et } \\
\text { al., } \\
2016(78)\end{array}$ & $\begin{array}{l}\text { Human } \\
\text { study }\end{array}$ & $\begin{array}{l}448 \text { (females and } \\
\text { males) }\end{array}$ & Energy expenditure & Aging accelerated \\
\hline $\begin{array}{l}\text { Munro D et } \\
\text { al., } \\
2019(79)\end{array}$ & $\begin{array}{l}\text { Animal } \\
\text { study }\end{array}$ & - & $\begin{array}{l}\text { Mitochondrial } \\
\text { metabolism }\end{array}$ & Aging accelerated \\
\hline $\begin{array}{l}\text { Zampino M } \\
\text { et al., } \\
2020(80)\end{array}$ & $\begin{array}{l}\text { Human } \\
\text { study }\end{array}$ & $\begin{array}{l}619 \text { men and women } \\
\text { aged } 24-97 \text { years }\end{array}$ & $\begin{array}{l}\text { Mitochondrial } \\
\text { function and Resting } \\
\text { metabolic rate }\end{array}$ & Aging accelerated \\
\hline $\begin{array}{l}\text { Boyce A et } \\
\text { al, 2020(8) }\end{array}$ & $\begin{array}{l}\text { Animal } \\
\text { study }\end{array}$ & $\begin{array}{l}46 \text { species, and from } \\
\text { literature data across } \\
147 \text { species }\end{array}$ & $\begin{array}{l}\text { Resting metabolic } \\
\text { rate }\end{array}$ & Lower survival \\
\hline $\begin{array}{l}\text { Protsiv M et } \\
\text { al, 2020(81) }\end{array}$ & $\begin{array}{l}\text { Human } \\
\text { study }\end{array}$ & $\begin{array}{l}677423 \text { human body } \\
\text { temperature } \\
\text { measurements }\end{array}$ & $\begin{array}{l}\text { Body temperature } \\
\text { from } 1860 \text { to } 2017\end{array}$ & Lower lifespan \\
\hline $\begin{array}{l}\text { Kelemen E } \\
\text { et al, } \\
2019(82)\end{array}$ & $\begin{array}{l}\text { Animal } \\
\text { study }\end{array}$ & Bumble bees & $\begin{array}{l}\text { Resting metabolic } \\
\text { rate }\end{array}$ & Lower lifespan \\
\hline $\begin{array}{l}\text { Most J et } \\
\text { al., } \\
2020(15)\end{array}$ & $\begin{array}{l}\text { Human } \\
\text { studies }\end{array}$ & $>10500$ & $\begin{array}{l}\text { Total daily energy } \\
\text { expenditure }\end{array}$ & Aging accelerated \\
\hline \multicolumn{5}{|c|}{$\begin{array}{l}\text { Increase in metabolic rate (MR) considered if: mitochondrial oxidative; Biological age (systolic and } \\
\text { diastolic blood pressure, forced lung capacity, expiratory breath-holding, crystalline accommodation, } \\
\text { acuity of hearing or auditory threshold under } 4,000 \mathrm{~Hz} \text {, body mass, self-evaluation of health status; } \\
\text { weight gain). }\end{array}$} \\
\hline
\end{tabular}

Overweight is the cause of higher energy expenditure. (41) Greater mass demands higher BMR. Overweight burns more calories. Decreasing fat mass reduces BMR, increases lifespan. $(3,42)$ One 
kilogram overweight deprives $\approx 50 \mathrm{kcal} /$ day of daily energy expenditure. (43) Overweight shortens lifespan, and weight loss increases it. (44)

Overfat gain is unfavorable process for body energy. Overweight increases the total pool metabolites. (42, 45) Overweight reduces tolerance to physical/mental stress. (9)

For each $100-\mathrm{kcal} /$ day increase in energy expenditure, the mortality risk increases by 1.3. Higher MR for 24-hour energy expenditure predicts early mortality and aging. (46) Overweight and increased MR cause faster body aging.

Energy expenditure depends on bodyweight. The heavier the body, the more energy he expends for living. $(19,47)$ Obesity significantly increases energy expenditure.

The highest amount of metabolism is expended to ensure nutritional (digestive) and reproductive metabolism. (48) Hyperactive sex reduces the total body energy that shortens lifespan. (49) Sex hormones play energetic role. (50) Sexual intercourse decreases sex hormones. The body makes an extra effort to restore the sex hormones reserve. (51)

\section{Overweight, Metabolic rate, Diseases, Time-flow perception}

Every disease increases in MR. (52) Patients with overweight expends more energy than healthy overweight people. (53)

Every sick person has a delayed TFP. (54) Sick has more complaints related to impatience to achieve outcomes and rush events. Delayed TFP is associated with increase in MR in patients. $(30,55)$ Increased blood pressure, heart rate, respiratory rate, local/overall temperature, sweating, synthesis of enzymes/hormones, immunological system activation, secretions (sputum, sweat, urine, feces, etc.) indicate on increased MR.

Every sick person has a higher MR and expends more own vital energy than healthy. (56) Every tired person has delayed TFP as a sick. Both are too impatient to achieve results, rush events.

Overweight correlates with onset/development diseases such as diabetes mellitus, hypertension, allergic and inflammatory diseases, urolithiasis and cholelithiasis, liver fibrosis, and tumor. $(1,57)$

\section{Individual bodyweight, Potential body energy, Lifespan}

To accumulate fat mass ability is one of the basis to survive at food deficiency. Food deficiency accompanied the humankind continuously. Currently, the survival ability leads to obesity-epidemic. $(1,19)$

Every person has own individual bodyweight. Normal bodyweight is when the body does not suffer from any diseases. The more potential the body has, the more weight he can gain. Weightgain is limited due to body potential. Weight limit is when weight cannot increase, and when weight stables at the highest point of weightgain that is 'terminal bodyweight'. Bodyweight is an integral indicator of body energy. 
Disease is an energy crisis signal. Each disease is accompanied by weight loss. $(13,55)$ Weight loss helps to recover. Simple restriction of food intake decreases MR by 45\%. (23) Decreasing MR is the saving body ability at food shortage.

Weightloss creates 'the power to weight gain'. 'The weightgain power' allows to recover from diseases, increases physical/mental activity. Weightloss recovers from a lot of chronic diseases such as hypertension, gastric ulcer, psoriasis, diabetes, bronchial asthma, neoplasms, urolithiasis, gallstone disease, and etc. $(13,58-61)$

Overeating at overweight deteriorates digestive; leads to malnutrition, metabolic intoxication, and immune stress. (62) Alimentary energy is energy expenditure for food intake, digestive, absorption, transport, storage, and eliminating.

Bodyweight tends to increase with age and it is only associated with fat gain. (10) The amount/stage of chronic diseases increase with age as well. (63) Various diseases is associated with individual chronobiorhythms. (2) Overweight is a consensus between body potential and nutrient reserve.

\section{Aging, Metabolic rate, Weight loss}

Effect of calorie restriction on aging and age-related diseases is well described. $(9,64)$ Overweight is a central role of many age-related chronic diseases and aging. (65)

Why weightloss is not easy in practice? The lower food intake, the greater percentage of nutrient absorption, and vice versa. Therefore, every diet should use a very low-calorie, or 'zero calories' diet. (5961) Under-utilized method of weight loss achieved with very-low-calorie diet allows activating endogenous lipolysis.

MR decreases with age. (66) Body under the Earth gravitation takes place in the energy-saving mode to prolong lifespan. Energy expenditure becomes careful with age and makes lifespan as unlimited $(34,67)$

Decreasing MR with age is not aging sign, it is energy expenditure adaptation mode. Weight loss optimizes MR, creates 'weightgain power'. The greatest reduction of total energy expenditure (including BMR, active expenditure, food thermic effect) after weight loss clearly shows how the body spent own energy to maintain overweight. (68)

Overweight is useless cycle of adenosine triphosphate consumption. (69) However, not every weightloss gives positive for the body. Some weightloss methods are not profitable to recover from diseases. Weightloss under chronic/neoplastic diseases leads to energy expenditure, whereas weightloss on restriction diet leads to energy saving. The growth of lifespan in most countries is more associated with improvement of household living conditions, saving heating energy; improving hygiene/sanitary conditions, decreasing infectious diseases; greater safety for living; fewer threats from wild animals, military actions. $(1,3)$ 
We should use weightloss methods getting energy from fat burning. Fat is a source of energy, but fat is getting older/denser if don't use it. Old fat absorbs intermediate/final metabolic products, which induces metabolic intoxication during weightloss. During weightloss should manage the intoxication.

Endogenous lipolysis provides the body with nutrients, vitamins, trace elements. $(59,60)$ Endogenous lipolysis starts only after ending of carbohydrate store, after 4-5 days of restriction diet. (70) Having a single meal per workday (usually after workhours) could be one of the modes to prevent weight regain. $(60,71)$

\section{Conclusions}

(1) Body mass and food intake are the main causes to maintain MR. Overweight is a balance between body potential and nutrient reserve.

(2) Overweight increases MR. MR inversely correlates to TFP. With aging MR decreases and TFP accelerates. MR decreasing with age is a sign of body energy-saving mode to prolong lifespan.

(3) MR elevates during body growth and decreases with age as well. Overweight increases energy expenditure. MR inversely correlates to lifespan. Increased MR accelerates aging. Hyperactive sex life reduces lifespan.

(4) Sick body has an increased MR and delayed TFP. Weightgain depletes body potential. Bodyweight at 'terminal overweight' is the base for diseases development. Overweight is a soil to grow diseases; devours body potential.

(5) Overeating at overweight worsens digestive process. Weightloss creates 'the power to weight gain' that increases physical/mental activity or weight regain.

(6) Weightloss optimizes MR. Old fat absorbs metabolic products. During weight loss should manage an endogen metabolic intoxication. Very-low-calorie diet should use for weight loss to activate endogenous lipolysis.

Study limitations: This study has several limitations.

First, the study was not designed as meta-analysis.

Second, published studies about the positive role of weight loss on MR, time perception, chronic diseases, aging, and lifespan are very limited in scope and number.

Third, the study included different studies including systematic reviews, non-randomized, and randomized studies.

Further multicenter randomized controlled trials are needed. 


\section{Abbreviations}

BMR: basal metabolic rate

MR: metabolic rate

TFP: time-flow perception.

\section{Declarations}

Ethics approval and consent to participate. Not applicable

Consent for publication. Our manuscript does not contain any individual person's data in any form. All authors of the manuscript affirm that they had access to the study data and reviewed and approved the final manuscript.

Availability of supporting data. Not applicable.

Competing interest. The authors declare that they have no any competing interests (financial, professional, or personals) that are relevant to the manuscript. We have read and understood the journal policy on declaration of interests and have no interests to declare.

Funding: This research did not receive any funding from public, commercial, or not-for-profit sectors.

Authors' contributions: $K O$ : design and performance, narrative analysis and review, bibliography review, data collection, scientific analysis, scientific executor, writing, editing, and revision. GB: study design, writing the discussion, bibliography and paper review. MG: design and performance, scientific analysis, bibliography and paper review. BD: preparation e-version data collection, bibliography and paper review, scientific analysis, writing the methods. $A T$ : scientific analysis, paper scientific review, writing the methods and print. ARS: study design, research executor, editing, and revision.

Acknowledgments. The authors thank very much Gulnur Zhakhina for English improvement and technical assistance.

Authors will provide an appropriate point-by-point response to the reviewer(s) which addresses their comments.

\section{References}

1. NCD NCDRFC. NCD Risk Factor Collaboration (NCD-RisC). Worldwide trends in diabetes since 1980: a pooled analysis of 751 population-based studies with 4.4 million participants (vol 387, pg 1513, 2016). Lancet. 2017;389(10068):E2-E.

2. Khatami M. Cancer; an induced disease of twentieth century! Induction of tolerance, increased entropy and 'Dark Energy': loss of biorhythms (Anabolism v. Catabolism). Clinical and Translational 
Medicine. 2018;7.

3. Broskey NT, Marlatt KL, Most J, Erickson ML, Irving BA, Redman LM. The Panacea of Human Aging: Calorie Restriction Versus Exercise. Exercise and Sport Sciences Reviews. 2019;47(3):169-75.

4. Sabounchi NS, Rahmandad H, Ammerman A. Best-fitting prediction equations for basal metabolic rate: informing obesity interventions in diverse populations. International Journal of Obesity. 2013;37(10):1364-70.

5. Melvin RG, Van Voorhies WA, Ballard JWO. Working harder to stay alive: Metabolic rate increases with age in Drosophila simulans but does not correlate with life span. Journal of Insect Physiology. 2007;53(12):1300-6.

6. Kelesidis T, Schmid I. Assessment of Telomere Length, Phenotype, and DNA Content. Current protocols in cytometry. 2017;79:7.26.1-7..3.

7. Mockett RJ, Sohal RS. Temperature-dependent trade-offs between longevity and fertility in the Drosophila mutant, methuselah. Experimental Gerontology. 2006;41(6):566-73.

8. Boyce AJ, Mouton JC, Lloyd P, Wolf BO, Martin TE. Metabolic rate is negatively linked to adult survival but does not explain latitudinal differences in songbirds. Ecology Letters. 2020;23(4):642-52.

9. Salvestrini V, Sell C, Lorenzini A. Obesity May Accelerate the Aging Process. Frontiers in Endocrinology. 2019;10.

10. Bowman K, Atkins JL, Delgado J, Kos K, Kuchel GA, Ble A, et al. Central adiposity and the overweight risk paradox in aging: follow-up of 130,473 UK Biobank participants. American Journal of Clinical Nutrition. 2017;106(1):130-5.

11. Conway LG, III, Repke MA, Houck SC. Psychological Spacetime: Implications of Relativity Theory for Time Perception. Sage Open. 2016;6(4).

12. Matthews WJ, Gheorghiu Al. Repetition, expectation, and the perception of time. Current Opinion in Behavioral Sciences. 2016;8:110-6.

13. Haywood CJ, Prendergast LA, Lim R, Lappas M, Lim WK, Proietto J. Obesity in older adults: Effect of degree of weight loss on cardiovascular markers and medications. Clinical Obesity. 2019;9(4).

14. Mueller MJ, Geisler C. From the past to future: from energy expenditure to energy intake to energy expenditure. European Journal of Clinical Nutrition. 2017;71(3):358-64.

15. Most J, Redman LM. Impact of calorie restriction on energy metabolism in humans. Experimental Gerontology. 2020;133.

16. Cvetkovic B, Gjoreski M, Sorn J, Maslov P, Lustrek M. Monitoring Physical Activity and Mental Stress Using Wrist-Worn Device and a Smartphone. Machine Learning and Knowledge Discovery in Databases, Ecml Pkdd 2017, Pt lii. 2017;10536:414-8.

17. Camps SG, Wang NX, Tan WSK, Henry CJ. Estimation of basal metabolic rate in Chinese: are the current prediction equations applicable? Nutrition Journal. 2016;15.

18. Piers LS, Shetty PS. BASAL METABOLIC RATES OF INDIAN WOMEN. European Journal of Clinical Nutrition. 1993;47(8):586-91. 
19. Jesus P, Achamrah N, Grigioni S, Charles J, Rimbert A, Folope V, et al. Validity of predictive equations for resting energy expenditure according to the body mass index in a population of 1726 patients followed in a Nutrition Unit. Clinical Nutrition. 2015;34(3):529-35.

20. de Jonge L, DeLany JP, Nguyen T, Howard J, Hadley EC, Redman LM, et al. Validation study of energy expenditure and intake during calorie restriction using doubly labeled water and changes in body composition. American Journal of Clinical Nutrition. 2007;85(1):73-9.

21. Lemay V, Drapeau V, Tremblay A, Mathieu ME. Exercise and negative energy balance in males who perform mental work. Pediatric Obesity. 2014;9(4):300-9.

22. Piaggi P, Thearle MS, Krakoff J, Votruba SB. Higher Daily Energy Expenditure and Respiratory Quotient, Rather Than Fat-Free Mass, Independently Determine Greater ad Libitum Overeating. Journal of Clinical Endocrinology \& Metabolism. 2015;100(8):3011-20.

23. Mitchell SE, Tang Z, Kerbois C, Delville C, Derous D, Green CL, et al. The effects of graded levels of calorie restriction: VIII. Impact of short term calorie and protein restriction on basal metabolic rate in the C57BL/ 6 mouse. Oncotarget. 2017;8(11):17453-74.

24. Bajotto G, Shimomura Y. Determinants of disuse-induced skeletal muscle atrophy: Exercise and nutrition countermeasures to prevent protein loss. Journal of Nutritional Science and Vitaminology. 2006;52(4):233-47.

25. Gurzadyan VG, Margaryan AT. The light speed versus the observer: the Kennedy-Thorndike test from GRAAL-ESRF. European Physical Journal C. 2018;78(8).

26. Uggerhoj UI, Mikkelsen RE, Faye J. The young centre of the Earth. European Journal of Physics. 2016;37(3).

27. Carr CE, Newman DJ. Space suit bioenergetics: Framework and analysis of unsuited and suited activity. Aviation Space and Environmental Medicine. 2007;78(11):1013-22.

28. Blanc S, Geloen A, Normand S, Gharib C, Somody L. Simulated weightlessness alters the nycthemeral distribution of energy expenditure in rats. Journal of Experimental Biology. 2001;204(23):4107-13.

29. Wittmann M, Lehnhoff S. Age effects in perception of time. Psychological Reports. 2005;97(3):92135.

30. Healy K, McNally L, Ruxton GD, Cooper N, Jackson AL. Metabolic rate and body size are linked with perception of temporal information. Animal Behaviour. 2013;86(4):685-96.

31. Zhang Y, Wu J, Hong P, Mao D, Zhuo Q, Chen X, et al. Basal metabolic rate of overweight and obese adults in Beijing. Wei sheng yan jiu = Journal of hygiene research. 2016;45(5):739-48.

32. Welle S, Forbes GB, Statt M, Barnard RR, Amatruda JM. ENERGY-EXPENDITURE UNDER FREE-LIVING CONDITIONS IN NORMAL-WEIGHT AND OVERWEIGHT WOMEN. American Journal of Clinical Nutrition. 1992;55(1):14-21.

33. Hancock PA. The effect of age and sex on the perception of time in life. American Journal of Psychology. 2010;123(1):1-13. 
34. Barbi E, Lagona F, Marsili M, Vaupel JW, Wachter KW. The plateau of human mortality: Demography of longevity pioneers. Science. 2018;360(6396):1459-61.

35. Harms JK. Time-lapsed reality visual metabolic rate and quantum time and space. Kybernetes. 2003;32(7-8):1113-28.

36. Westerterp KR, Goran MI. Relationship between physical activity related energy expenditure and body composition: A gender difference. International Journal of Obesity. 1997;21(3):184-8.

37. Tsai SB, Tucci V, Uchiyama J, Fabian NJ, Lin MC, Bayliss PE, et al. Differential effects of genotoxic stress on both concurrent body growth and gradual senescence in the adult zebrafish. Aging Cell. 2007;6(2):209-24.

38. Polymenis M, Kennedy BK. Unbalanced Growth, Senescence and Aging. Cell Division Machinery and Disease. 2017;1002:189-208.

39. Hayflick L. THE LIMITED IN VITRO LIFETIME OF HUMAN DIPLOID CELL STRAINS. Experimental cell research. 1965;37:614-36.

40. Moss DK, Ivany LC, Judd EJ, Cummings PW, Bearden CE, Kim W-J, et al. Lifespan, growth rate, and body size across latitude in marine Bivalvia, with implications for Phanerozoic evolution.

Proceedings of the Royal Society B-Biological Sciences. 2016;283(1836).

41. Heymsfield SB, Thomas DM, Bosy-Westphal A, Mueller MJ. The anatomy of resting energy expenditure: body composition mechanisms. European Journal of Clinical Nutrition. 2019;73(2):16671.

42. Bordone L, Guarente L. Calorie restriction, SIRT1 and metabolism: Understanding longevity. Nature Reviews Molecular Cell Biology. 2005;6(4):298-305.

43. Hintze LJ, Goldfield G, Seguin R, Damphousse A, Riopel A, Doucet E. The rate of weight loss does not affect resting energy expenditure and appetite sensations differently in women living with overweight and obesity. Physiology \& Behavior. 2019;199:314-21.

44. Redman LM, Ravussin E. Caloric Restriction in Humans: Impact on Physiological, Psychological, and Behavioral Outcomes. Antioxidants \& Redox Signaling. 2011;14(2):275-87.

45. Piaggi P, Thearle MS, Bogardus C, Krakoff J. Fasting Hyperglycemia Predicts Lower Rates of Weight Gain by Increased Energy Expenditure and Fat Oxidation Rate. Journal of Clinical Endocrinology \& Metabolism. 2015;100(3):1078-87.

46. Jumpertz R, Hanson RL, Sievers ML, Bennett PH, Nelson RG, Krakoff J. Higher Energy Expenditure in Humans Predicts Natural Mortality. Journal of Clinical Endocrinology \& Metabolism. 2011;96(6):E972-E6.

47. Schutz Y, Weinsier RL, Hunter GR. Assessment of free-living physical activity in humans: An overview of currently available and proposed new measures. Obesity Research. 2001;9(6):368-79.

48. Ellison PT. Energetics and reproductive effort. American Journal of Human Biology. 2003;15(3):34251. 
49. Salomon TB, Benfato MS. Sexual activity affects the redox profile along the aging process in male rats. Biogerontology. 2018;19(1):13-21.

50. Jasienska G, Bribiescas RG, Furberg A-S, Helle S, Nunez-de la Mora A. Human reproduction and health: an evolutionary perspective. Lancet. 2017;390(10093):510-20.

51. Sztajzel J, Periat M, Marti V, Krall P, Rutishauser W. Effect of sexual activity on cycle ergometer stress test parameters, on plasmatic testosterone levels and on concentration capacity - A study in highlevel male athletes performed in the laboratory. Journal of Sports Medicine and Physical Fitness. 2000;40(3):233-9.

52. Morino K, Kondo K, Tanaka S, Nishida Y, Nakae S, Yamada Y, et al. Total energy expenditure is comparable between patients with and without diabetes mellitus: Clinical Evaluation of Energy Requirements in Patients with Diabetes Mellitus (CLEVER-DM) Study. Bmj Open Diabetes Research \& Care. 2019;7(1).

53. Pujia A, Gazzaruso C, Ferro Y, Mazza E, Maurotti S, Russo C, et al. Individuals with Metabolically Healthy Overweight/Obesity Have Higher Fat Utilization than Metabolically Unhealthy Individuals. Nutrients. 2016;8(1).

54. Kowacs PA, Piovesan EJ, Werneck LC, Fameli H, Zani AC, da Silva HP. Critical flicker frequency in migraine. A controlled study in patients without prophylactic therapy. Cephalalgia. 2005;25(5):33943.

55. Caron N, Peyrot N, Caderby T, Verkindt C, Dalleau G. Energy Expenditure in People with Diabetes Mellitus: A Review. Frontiers in Nutrition. 2016;3.

56. Wu J, Mao D, Zhang Y, Chen X, Hong P, Piao J, et al. Basal energy expenditure, resting energy expenditure and one metabolic equivalent (1 MET) values for young Chinese adults with different body weights. Asia Pacific Journal of Clinical Nutrition. 2019;28(1):35-41.

57. Lopes LL, Bressan J, Peluzio MdCG, Hermsdorff HHM. LINE-1 in Obesity and Cardiometabolic Diseases: A Systematic Review. Journal of the American College of Nutrition. 2019;38(5):478-84.

58. de Menezes MC, Duarte CK, Costa DVD, Lopes MS, de Freitas PP, Campos SF, et al. A systematic review of effects, potentialities, and limitations of nutritional interventions aimed at managing obesity in primary and secondary health care. Nutrition. 2020;75-76.

59. Oshakbayev K, Dukenbayeva B, Togizbayeva G, Durmanova A, Gazaliyeva M, Sabir A, et al. Weight loss technology for people with treated type 2 diabetes: a randomized controlled trial. Nutrition \& Metabolism. 2017;14.

60. Oshakbayev K, Dukenbayeva B, Otarbayev N, Togizbayeva G, Tabynbayev N, Gazaliyeva M, et al. Weight loss therapy for clinical management of patients with some atherosclerotic diseases: a randomized clinical trial. Nutrition Journal. 2015;14.

61. Oshakbayev KP, Alibek K, Ponomarev IO, Uderbayev NN, Dukenbayeva BA. Weight change therapy as a potential treatment for end-stage ovarian carcinoma. Am J Case Rep. 2014;15:203-11.

62. Ozkaya I, Gurbuz M. Malnourishment in the overweight and obese elderly. Nutricion Hospitalaria. 2019;36(1):39-42. 
63. Santulli G, Ciccarelli M, Trimarco B, laccarino G. Physical activity ameliorates cardiovascular health in elderly subjects: the functional role of the beta adrenergic system. Frontiers in Physiology. 2013;4.

64. Li X-D, Rebrin I, Forster MJ, Sohal RS. Effects of age and caloric restriction on mitochondrial protein oxidative damage in mice. Mechanisms of Ageing and Development. 2012;133(1):30-6.

65. Rizza W, Veronese N, Fontana L. What are the roles of calorie restriction and diet quality in promoting healthy longevity? Ageing Research Reviews. 2014;13:38-45.

66. Elia M, Ritz P, Stubbs RJ. Total energy expenditure in the elderly. European Journal of Clinical Nutrition. 2000;54:S92-S103.

67. Goldsmith TC. Modern evolutionary mechanics theories and resolving the programmed/nonprogrammed aging controversy. Biochemistry-Moscow. 2014;79(10):1049-55.

68. Müller MJ, Enderle J, Bosy-Westphal A. Changes in Energy Expenditure with Weight Gain and Weight Loss in Humans. Current Obesity Reports. 2016;5(4):413-23.

69. Liu J, Wang Y, Lin L. Small molecules for fat combustion: targeting obesity. Acta Pharmaceutica Sinica B. 2019;9(2):220-36.

70. Soeters M, Soeters P, Schooneman M, Houten S, Romijn J. Adaptive reciprocity of lipid and glucose metabolism in human short-term starvation. American Journal of Physiology-Endocrinology and Metabolism. 2012;303(12):E1397-E407.

71. Kahleova H, Lloren Jl, Mashchak A, Hill M, Fraser GE. Meal Frequency and Timing Are Associated with Changes in Body Mass Index in Adventist Health Study 2. Journal of Nutrition. 2017;147(9):1722-8.

72. Ulmer HV. Concept of an extracellular regulation of muscular metabolic rate during heavy exercise in humans by psychophysiological feedback. Experientia. 1996;52(5):416-20.

73. Misanin JR, Wilson HA, Schwarz PR, Tuschak JB, Hinderliter CF. Low body temperature affects associative processes in long-trace conditioned flavor aversion. Physiology \& Behavior. 1998;65(3):581-90.

74. Block RA, Zakay D, Hancock PA. Developmental changes in human duration judgments: A metaanalytic review. Developmental Review. 1999;19(1):183-211.

75. Negasheva M, Lapshina N, Okushko R, Godina E. Biological age and tempos of aging in women over 60 in connection with their morphofunctional characteristics. Journal of Physiological Anthropology. 2014;33:7.

76. Keil G, Cummings E, de Magalhaes JP. Being cool: how body temperature influences ageing and longevity. Biogerontology. 2015;16(4):383-97.

77. Ravussin E, Redman LM, Rochon J, Das SK, Fontana L, Kraus WE, et al. A 2-Year Randomized Controlled Trial of Human Caloric Restriction: Feasibility and Effects on Predictors of Health Span and Longevity. Journals of Gerontology Series a-Biological Sciences and Medical Sciences. 2015;70(9):1097-104. 
78. Geisler C, Braun W, Pourhassan M, Schweitzer L, Glueer C-C, Bosy-Westphal A, et al. Gender-Specific Associations in Age-Related Changes in Resting Energy Expenditure (REE) and MRI Measured Body Composition in Healthy Caucasians. Journals of Gerontology Series a-Biological Sciences and Medical Sciences. 2016;71(7):941-6.

79. Munro D, Pamenter ME. Comparative studies of mitochondrial reactive oxygen species in animal longevity: Technical pitfalls and possibilities. Aging Cell. 2019;18(5).

80. Zampino M, Semba RD, Adelnia F, Spencer RG, Fishbein KW, Schrack JA, et al. Greater skeletal muscle oxidative capacity is associated with higher resting metabolic rate: results from the Baltimore Longitudinal Study of Aging. The journals of gerontology Series A, Biological sciences and medical sciences. 2020.

81. Protsiv M, Ley C, Lankester J, Hastie T, Parsonnet J. Decreasing human body temperature in the United States since the industrial revolution. Elife. 2020;9.

82. Kelemen EP, Cao N, Cao T, Davidowitz G, Dornhaus A. Metabolic rate predicts the lifespan of workers in the bumble bee Bombus impatiens. Apidologie. 2019;50(2):195-203.

\section{Figures}




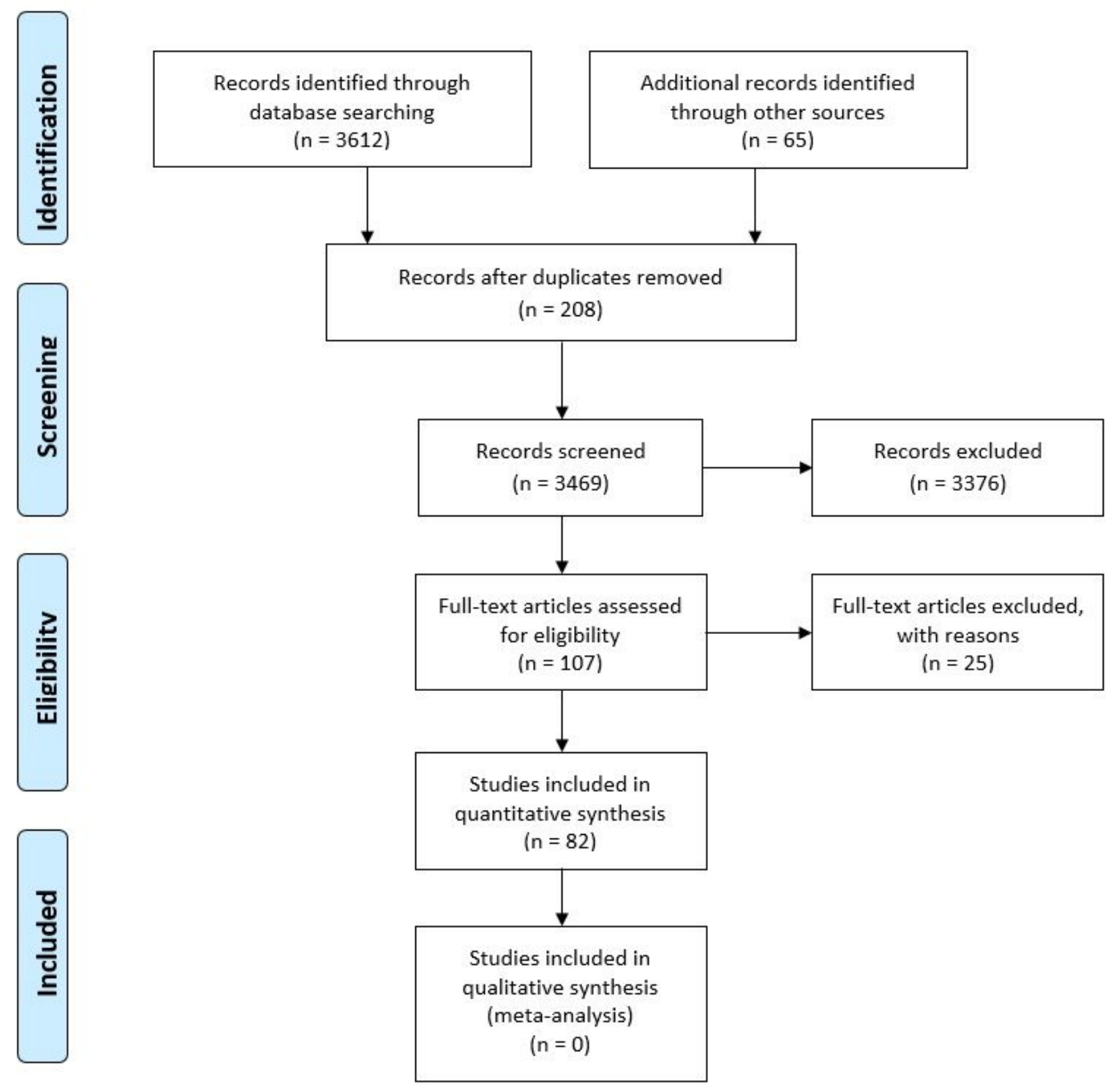

Figure 1

PRISMA Flow Diagram

\section{Supplementary Files}

This is a list of supplementary files associated with this preprint. Click to download.

- PRISMAchecklist.doc 